\title{
Transient versus Persistent Functional and Structural Changes Associated with Facilitation of Aplysia Sensorimotor Synapses Are Second Messenger Dependent
}

\author{
Fang Wu, Leah Friedman, and Samuel Schacher \\ Center for Neurobiology and Behavior, Columbia University College of Physicians and Surgeons, and New York \\ State Psychiatric Institute, New York, New York 10032
}

Increases in activity of both protein kinase A (PKA) and protein kinase $C$ (PKC) contribute to short-term facilitation of Ap/ysia sensorimotor synapses evoked by serotonin (5HT). We report here that increasing levels of cAMP in sensory neurons evokes increases in both synaptic efficacy and in the number of sensory neuron varicosities contacting the major axons of motor cell L7 at intermediate times (3 hr) that persist for $24 \mathrm{hr}$. Treatment with phorbol esters results in a large transient increase in synaptic efficacy that is accompanied by a large transient increase in the number of sensory neuron varicosities with the newest varicosities most susceptible to elimination. The reversal of the synaptic facilitation and the structural changes does not appear to be the result of long-term inhibitory actions of persistent PKC activation by phorbol esters, since changes in synaptic efficacy can be evoked by additional applications of either phorbol esters or 5-HT. The shortlived changes in structure evoked by phorbol esters occur in preexisting sensory neurites and not by new growth, since increases in PKC activity with phorbol esters lead to reductions in neurite extension and to retractions by sensory neuron growth cones. The action of phorbol esters on growth cone extension is reversible with washout. The results suggest that increases in PKA and PKC activities by 5-HT contribute to short (minutes) and intermediate (hours) forms of facilitation of sensorimotor synapses while increases in PKA activity also mediate long-term (days) maintenance of synaptic facilitation.

[Key words: protein kinase A, protein kinase C, synaptic plasticity, intermediate term, long term, sensorimotor synapse, Aplysia]

Changes in the activity of protein kinases play important roles in mediating short- and long-term changes in the properties of mature neurons and their connections. Changes in kinase activities influence ionic conductances and excitability (Kandel and Schwartz, 1982; Acousta-Urquidi et al., 1984; Farly and Auer-

\footnotetext{
Received May 24, 1995: revised July 14, 1995; accepted July 19, 1995.

We thank Robert Woolley for assistance in preparing the figures, and Drs. J. Koester, 1. Kupfermann, and J. H. Schwarty for helpful comments on earlier drafts of the manuscript. This research was supported by NIH Grants GM 32099 and NS 27541

Correspondence should be addressed to Samuel Schacher, Center for Neurobiology and Behavior, Columbia University College of Physicians and Sur geons, New York State Psychiatric Institute, 722 West 168th Street, New York, NY 10032.

Copyright $(c) 1995$ Society for Neuroscience $0270-6474 / 95 / 157517-11 \$ 05.00 / 0$
}

bach, 1986; Miller et al., 1992; McGlade-McCulloh et al., 1993; Raymond et al., 1993; Wang et al., 1994), the efficacy of synaptic transmission (Kandel and Schwartz, 1982; Malinow et al., 1988; Dixon and Atwood; 1989; Schuman and Clark, 1994), or the number and structural properties of transmitter release sites (Wojtowitz et al., 1989; Corfas and Dudai, 1991; Nazif et al., 1991; Zhong and Wu, 1991; Schacher et al., 1993). In some forms of hippocampal LTP, changes in the activities of several kinases, such as certain forms of $\mathrm{Ca}$ /calmodulin kinase (Malenka ct al., 1989; Malinow et al., 1989; Silva et al., 1992), tyrosine kinase (O'dell et al., 1991; Grant et al., 1992), protein kinase C (Akers et al., 1986; Hu et al., 1987; Malinow et al., 1989; Abeliovich et al., 1993), and protein kinase A (Frey et al., 1993; Bourtchuladze et al., 1994; Huang et al., 1994; Weisskopf et al., 1994), contribute in varying degrees to the induction or maintenance of the plasticity. The order of activation of these kinases, the critical substrates and sites of their activities in the presynaptic versus postsynaptic cells, and the time course of their activation and/or inactivation in mediating the change in synaptic function are not well understood.

Sensitization of defensive reflexes in Aplysia is mediated in part by the neurotransmitter 5-HT (Glanzman et al., 1989b) which evokes short- or long-term changes in the properties of the neurons in the circuit controlling the behaviors by affecting the activities of protein kinases. Various properties of mechanosensory cells are affected by 5-IIT: potassium and calcium conductances are altered which influence excitability and spike duration (Klein et al., 1982, 1986; Boyle et al., 1984; Ocorr and Byrne, 1985; Walsh and Byrne, 1989; Baxter and Byrne, 1990; Braha et al., 1993), evoked and spontaneous transmitter release from preexisting sensory terminals are increased (Brunelli et al., 1976; Hochner et al., 1986; Rayport and Schacher, 1986; Dale et al., 1988; Braha et al., 1990; Dale and Kandel, 1990; Klein, 1993, 1994), and the growth of new presynaptic branches and varicositics contacting target neurons are evoked with long-term facilitation (Glanzman et al., 1990; Bailey et al., 1992). Biochemical, physiological and pharmacological evidence indicate that many of the short-term changes in the sensory cells evoked by 5 -HT or sensitizing stimuli are mediated by increases in the activity of PKA and PKC (Brunelli et al., 1976; Castellucci et al., 1980, 1982; Bernier et al., 1982; Siegelbaum et al., 1982; Ocorr and Byrne, 1985; Klein et al., 1986; Braha el al., 1990; Sacktor and Schwartz, 1990; Mercer et al., 1991; Critz and Byrne, 1992; Sossin and Schwartz, 1992; Ghirardi et al., 1992; Sugita et al., 1992, 1994). Persistent activation of the PKA pathway (Greenberg et al., 1987; Sweatt and Kandel, 1989; Schacher 
et al., 1991; Backsai et al., 1993) can produce the long-term changes lasting at least $24 \mathrm{hr}$ that are evoked by 5 -HT or sensitization training: increases in synaptic efficacy (Schacher et al., 1988, 1993; Alberini et al., 1994), increases in the number of presynaptic varicosities and branches (Nazif et al., 1991; Schacher et al., 1993), and changes in potassium conductance (Scholz and Byrne, 1987, 1988). The contribution of 5-HT-induced increase in PKC activity to long-term presynaptic facilitation is not clear, since an increase in PKC activity with phorbol esters fails to evoke long-term facilitation (Schacher et al., 1988; Sossin et al., 1994) while pharmacological blockade primarily of the increase in PKC activity did not interfere with the expression of long term facilitation evoked with 5-HT (Emptage and Carew, 1993). However, recent evidence suggests that PKC activation may contribute to an intermediate phase of facilitation that lasts several hours. Treatments with 5-HT that evoke long-term facilitation first elicit a transient, protein synthesis-dependent phase of facilitation whose magnitude is greater than either short-term facilitation lasting minutes or long-term facilitation measured 24 hr after treatment (Ghirardi et al., 1995). Treatment with 5-HT or repeated sensitizing stimuli also evoke a persistent activation of some PKC isoforms in the sensory cells that lasts several hours after the completion of the facilitating stimulus (Sossin et al., 1994).

What are the contributions of increasing the activity of each of these second messenger pathways in evoking functional and structural changes in the sensorimotor connection during intermediate phases of facilitation (hours) and to long-term facilitation (days)? Taking advantage of the simple in vitro preparation (Rayport and Schacher, 1986), we examined the functional and structural changes in sensorimotor connections over time following prolonged activation of each second messenger pathway. Increasing cAMP levels in the sensory neurons evoked a functional change at intermediate times (three hours), while the structural change is expressed partially at the intermediate time point and is further developed after $24 \mathrm{hr}$. By contrast, treatment with an activator of $\mathrm{PKC}$ evoked a large increase both in the efficacy of the connection and in the number of sensory varicosities at intermediate times, but these changes were no longer expressed by the cells $24 \mathrm{hr}$ after treatment. The decline in varicosity number after the intermediate time point was correlated with the elimination of the newest varicosities. Our results are consistent with the hypothesis that persistent activation of the PKC and PKA pathways by 5-HT can act in parallel in producing shortand intermediate-term synaptic facilitation of this connection. Persistent changes in synaptic efficacy and sensory neuron structure require the critical contribution of increases in PKA activity that stabilizes both local changes in preexisting terminals and neurites as well as other changes that are essential for the growth and maintenance of new presynaptic structures.

\section{Materials and Methods}

Cell culture. Mechanosensory neurons of Aplysia were isolated from the pleural ganglion dissected from adult animals $(70-100 \mathrm{gm})$ and were cultured either alone or cocultured with identified motor cell L7 isolated from the abdominal ganglion of juvenile animals (1-3 gm; University of Miami Mariculture Facility) and maintained for up to $5 \mathrm{~d}$ as described previously (Schacher and Proshansky, 1983; Schacher, 1985; Rayport and Schacher, 1986). Individual cells were isolated with a segment (100-600 $\mu \mathrm{m}$ ) of their original axons intact (Schacher and Proshansky, 1983). Each culture contained either a single sensory cell cocultured with a single L7 or 5-10 sensory cells. Cocultures were allowed to grow processes for $4 \mathrm{~d}$ to permit the establishment of stable synaptic contacts and neuritic arbors (Montarolo et al., 1986; Dale et al., 1988;
Glanzman et al., 1990; Schacher and Montarolo, 1991). Cultures with sensory cells alone were examined after $3 \mathrm{~d}$ to determine the effects of PKC activation during the period of rapid neurite growth (Peter et al., 1994).

Electrophysiology. The stimulation and recording techniques for measuring changes in the efficacy of the SN-L7 connection have been described (Montarolo et al., 1986). For monitoring changes in connectivity, the motor cell was impaled with a microelectrode (15-20 M $\Omega$ ) containing $2.0 \mathrm{M} \mathrm{KCl}$ and held at a potential of $-30 \mathrm{mV}$ below the resting level $(-49$ to $-65 \mathrm{mV})$ to permit accurate measurements of the amplitude of the EPSP. For each coculture, synaptic potentials were evoked in L7 before treatments and at 3 and $24 \mathrm{hr}$ after the onset of the control or experimental treatments by stimulating the sensory neuron with a single brief $(50 \mathrm{msec}$ ) depolarization using the dye-filled intracellular electrode after the iontophoretic injection of the dye. During the recording and dye-filling, cultures were superfused at $1 \mathrm{ml} / \mathrm{min}$ with medium consisting of artificial sea water (Instant Ocean) and modified L15 with salt concentrations added to levels consistent with sea water (Schacher et al., 1990).

Drug applications. After recording the initial amplitudes of the EPSPs and imaging sensory neurites interacting with the major axon of L7 (see below), cocultures were divided into four groups. Cultures were incubated for $2 \mathrm{hr}$ with $50 \mathrm{~nm}$ phorbol 12,13-dibutyrate (Sigma; PDBU or phorbol) or $100 \mathrm{~nm} 4 \alpha$-phorbol (Sigma; inactive form referred in the text as $\alpha$-phorbol) dissolved in perfusion medium. Alternatively, cAMP or 5'AMP (Sigma) was injected via iontophoresis for $10 \mathrm{~min}$ (Scholz and Byrne, 1988; Schacher et al, 1993) with intracellular microelectrodes filled with $200 \mathrm{~mm}$ cAMP or 5'AMP. Beginning $10 \mathrm{~min}$ before and ending $10 \mathrm{~min}$ after the injection, cultures were perfused with 100 $\mu \mathrm{M}$ IBMX (Sigma) in perfusion medium (Schacher et al., 1993). All cultures were rinsed $4 \times$ with perfusion medium, and reexamined three hours after starting drug incubation or intracellular injection. Cultures were rinsed with culture medium, placed back into the incubator and reexamined for a third time after $24 \mathrm{hr}$. Another set of cocultures were used to examine the long-term consequences of PDBU treatment. EPSPs were recorded before and $24 \mathrm{hr}$ after a $2 \mathrm{hr}$ treatment with PDBU or $\alpha$-phorbol as described above. At the second recording, either 5-HT $(2 \mu \mathrm{M})$ was applied to the cultures after the sensory neuron was given 10 stimuli at $30 \mathrm{sec}$ intervals to produce homosynaptic depression, or PDBU was applied for I $\mathrm{hr}$ after a single test stimulus to determine whether the synapse can undergo synaptic facilitation. To examine effects of PDBU on sensory neuron growth, cultures with sensory neurons only that had 10 or more sensory growth cones were first rinsed with perfusion medium and every growth cone was photographed before the $2 \mathrm{hr}$ incubation with PDBU or $\alpha$-phorbol. The cultures were rinsed with perfusion medium and neurites and growth cones re-photographed starting $30 \mathrm{~min}$ or $4 \mathrm{hr}$ after washout. Cultures treated with PDBU that had at least 10 growth cones that had stopped or retracted with treatment were reexamined at $4 \mathrm{hr}$ after washout. The percent for each growth cone behavior was measured in each culture and averaged over all the cultures (Peter et al., 1994).

Dye injection and imaging structural changes. The fluorescent dye 5(6)-carboxyfluorescein (Molecular Probes; $6 \%$ in $0.44 \mathrm{M} \mathrm{KOH;} \mathrm{pH}=$ 7.0) was injected into the sensory cell in the cocultures with $0.3-0.5$ $\mathrm{nA}$ hyperpolarizing current pulses $(500 \mathrm{msec}$ at $1 \mathrm{~Hz}$ ) for 5-6 $\mathrm{min}$ (Glanzman et al., 1989a: Schacher and Montarolo, 1991) at each time point. Nomarski contrast and fluorescent images of the same view areas along the major axons of the motor cell were taken both before and after treatments with a Nikon Diaphot microscope and a SIT (Dage 66) video camera. The images were processed by a Dell 310 computer with a PC Vision Plus frame grabber, and subsequently stored on a Panasonic optical disk drive. Alignment of the live view area at the $3 \mathrm{hr}$ and 24 hr time points with the initial recorded image was aided by the computer with fine adjustments made with the stage controls and by manual rotation of the culture dish. Illumination used for obtaining fluorescent images was kept as low as possible to prevent photodamage. To minimize differences in imaged structures that might arise as a result of differences in the extent of dye filling, light intensities used at the $3 \mathrm{hr}$ and $24 \mathrm{hr}$ points were adjusted to match the intensity of the stored images taken before treatment. Phase contrast Micrographs of the sensory growth cones before and after treatments were used to measure changes in growth cone behavior. Micrographs of the images were made with a Panasonic or Sony video printer.

Quantification of structural change. Counts of varicosity number were obtained from fluorescent images of sensory cell neurites con- 
tacting the axon hillock and major processes of L7. Previous studies had indicated that this region of L7 is the most favorable for the growth of sensory neurites, and contains most of the varicosities and transmitter release sites (Glanzman et al., 1989a, 1990; Schacher et al., 1991). Since the major axons of $\mathrm{L} 7$ are relatively thick structures, it often required as many as four different focal planes to image all of the labeled neurites and varicosities in a given view area. To minimize slight differences in focus which could obscure differences in varicosity number, we used computer-assisted superimposition of the various focal planes onto a single two-dimensional image. The matched fluorescent images of each focal plane along with the superimpositions for the three time points were compared and the total number of varicosities counted. Net change in varicosity number was measured for all treatments. We also examined the effect of treatment on the maintenance of the new varicosities. A varicosity (swelling along a sensory cell process greater than $2 \mu \mathrm{m}$ in diameter) was considered new if the structure was not located within a $2 \mu \mathrm{m}$ radius in the same region of the motor axon on an earlier image of the area. The varicosity was considered to be eliminated if the structure was absent within a $2 \mu \mathrm{m}$ radius in the same region of the motor axon. Structures that were slightly elongated spheres greater or equal to $2 \mu \mathrm{m}$ connected by narrow neuritic necks were counted as varicosities (Bailey and Chen, 1983, 1988). Counts of varicosities were performed blind; the individual did not know the amplitude of the EPSPs before or after treatment or the nature of the treatment. Growth cone behaviors in sensory neuron cultures were scored for extension or retraction behavior; growth of $10 \mu \mathrm{m}$ or more over the approximately $3 \mathrm{hr}$ time period was scored as extension; retraction of $10 \mu \mathrm{m}$ or more over the same period was scored as a retraction, and intermediate behavior was scored as a stop).

Analysis of data. All data are represented as the mean \pm SEM. Student $t$ tests (two-tailed) or ANOVA's (one- or two-factor) followed by corrected multicomparison $t$ tests (Dunnett's) were used to measure significance of the change in EPSP amplitude, and the number of sensory varicosities with treatment over time, and the effect of treatment on sensory neuron growth cone behavior.

\section{Results}

Activation of PKA pathway evokes an early change in both the function and structure of sensorimotor connections that persists for $24 \mathrm{hr}$

During the first $4 \mathrm{~d}$ in culture, the regenerating neurons reestablish stable functional connections (Rayport and Schacher, 1986; Glanzman et al., 1989a; Zhu et al., 1994). The stability of the connection is strongly correlated with the stability of the sensory neuron arbor both in the overall number of presynaptic varicosities interacting with the motor axon as well as in the maintenance of existing varicosities (Bank and Schacher, 1992; Zhu et al., 1995). Applications of 5-HT to 4 or $5 \mathrm{~d}$ old cultures evoke a functional change in the connection lasting at least $24 \mathrm{hr}$ that is accompanied by the formation of new sensory cell varicosities and transmitter release sites in contact with the major axonal processes of motor cell L7 (Glanzman et al., 1989a, 1990; Schacher et al., 1991). Recent studies indicated that the efficacy of sensorimotor connections show as much as a $200 \%$ enhancement at intermediate times $(0.5-3 \mathrm{hr})$ after repeated applications of 5 -HT compared to the long-term change of about $80 \%$ detected $24 \mathrm{hr}$ after treatment (Ghirardi et al., 1995). Raising intracellular cAMP in the sensory neurons (Schacher et al., 1993) evokes increases in the efficacy of the connection at both the short-term $(80 \%$ at $10 \mathrm{~min})$ and long-term $(60 \%$ at $24 \mathrm{hr})$ time points, and the long-term change with cAMP is accompanied by the formation of new sensory varicosities and branches (Schacher et al., 1993). We first examined whether raising cAMP levels in sensory cells with intracellular injections of cAMP evoke large functional and structural changes at an intermediate time point $(3 \mathrm{hr})$. We also compared the changes at $3 \mathrm{hr}$ to the changes observed for the same preparations at $24 \mathrm{hr}$. After allowing the cells to regenerate and form stable connections after

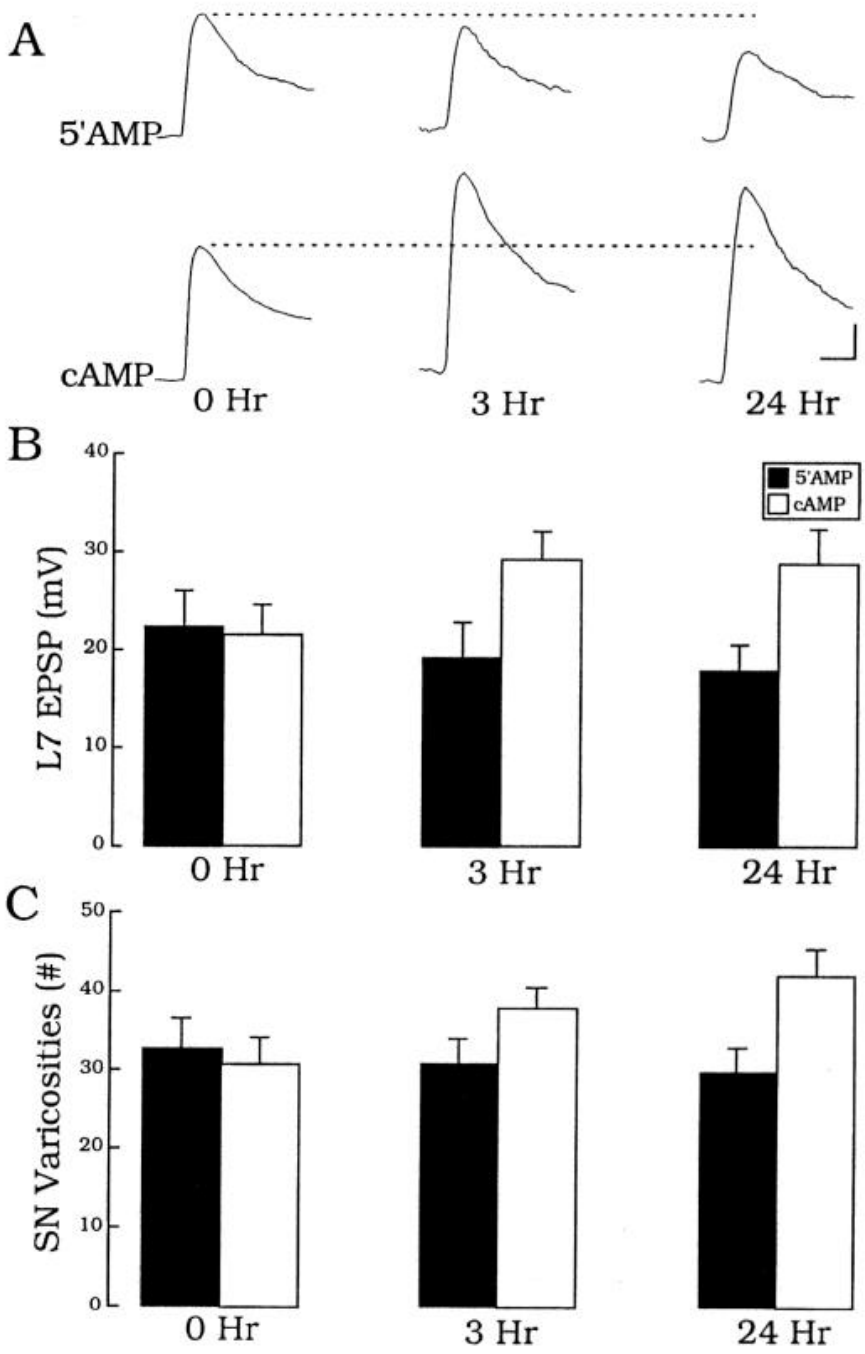

Figure 1. cAMP evoked persistent functional and structural changes in the SN-L7 connections. A, The efficacy of the connection is enhanced by injection with cAMP, but not with 5'AMP. EPSPs were recorded before $(0 \mathrm{hr})$ and twice after treatment $(3 \mathrm{hr}$ and $24 \mathrm{hr})$. Whereas the amplitude of the EPSP declines with 5'AMP (top), cAMP increases the EPSP amplitude both at $3 \mathrm{hr}$ and $24 \mathrm{hr}$. The vertical bar equals $5 \mathrm{mV}$, and the horizontal bar equals $10 \mathrm{msec} . B$, Summary of the changes in EPSP amplitude evoked by 5'AMP (solid bars) and cAMP (white bars). The height of each bar is the average ampltitude \pm SEM of the EPSP at each time point. A two-factor ANOVA indicated a significant effect of treatment over time ( $\mathrm{df}=2,28, F=53.778, p<0.001$ ). One-factor ANOVA and $t$ tests indicated that cAMP evoked a significant change in the EPSP amplitude at both the $3 \mathrm{hr}$ and $24 \mathrm{hr}$ time points. $C$, Summary of the changes in the number of sensory neuron varicosities evoked by 5'AMP and cAMP. The height of each bar is the average number of sensory varicosities \pm SEM at each time point. A two-factor ANOVA indicated a significant effect of treatment over time $(\mathrm{df}=2,28$, $F=42.813, p<0.001)$. One-factor ANOVA and $t$ tests indicated that cAMP evoked a significant change in varicosity number at both the 3 $\mathrm{hr}$ and $24 \mathrm{hr}$ time points. Note that the difference between cAMP and AMP at $24 \mathrm{hr}$ is greater than the difference at $3 \mathrm{hr}$.

$4 \mathrm{~d}$, the amplitude of the EPSP evoked in motor cell L7 was measured before and twice after (at $3 \mathrm{hr}$ and $24 \mathrm{hr}$ ) intracellular injection (10 $\mathrm{min}$ ) of cAMP or 5'AMP (Scholz et al., 1988; Nazif et al., 1991; Schacher et al., 1993). At the same time points, the structure of the sensory cell neurites interacting with major axonal processes of L7 were imaged and photographed following intracellular injection of the fluorescent dye 5(6) carboxyfluorescein (Glanzman et al., 1989a, 1990). 

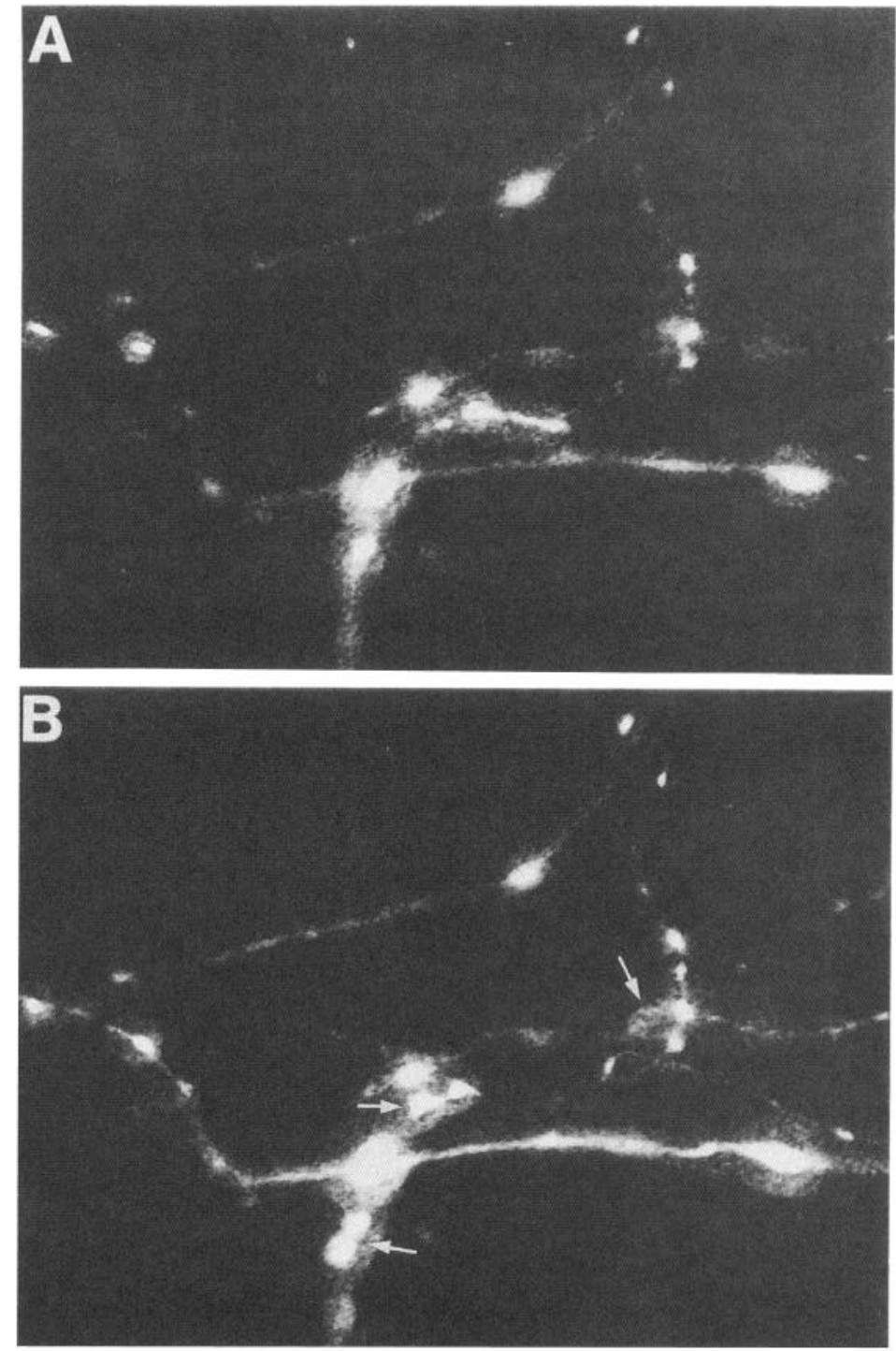

Figure 2. cAMP evoked a persistent change in the structure of the sensory neurons. $A$, Epifluorescent view of a portion of the sensory cell neurites and varicosities in contact with the major motor axon (middle half of micrograph in the horizontal plane) before injection with cAMP. Image is a superimposition of three focal planes photographed in this view area. $B$, View of the same area in $A 3 \mathrm{hr}$ after injection of cAMP. Three new varicosities (arrows) have formed in this region. Overall, this sensory neuron gained six varicosities. $C$, View of the same area at $24 \mathrm{hr}$. Note the new branches and varicosities (arrowhead) near the center of the field. There was a net gain of six varicosities in this region. Two of the three new varicosities (arrows) established at the $3 \mathrm{hr}$ time point are still present. Overall there was a net gain of 13 varicosities for this sensory neuron compared to the $0 \mathrm{hr}$ time point. Scale bar, $15 \mu \mathrm{m}$.

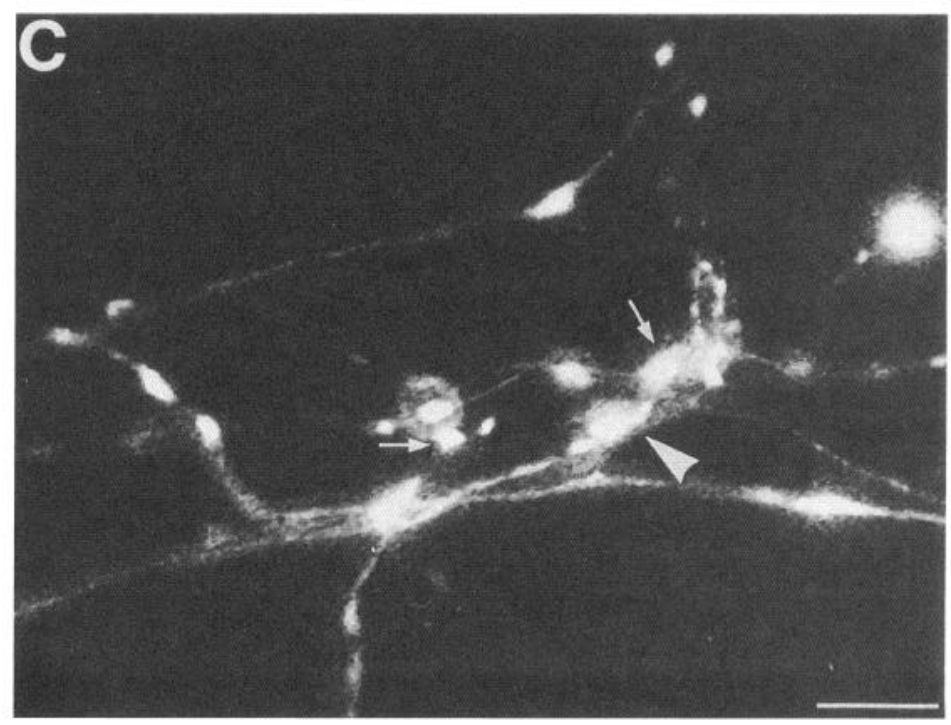


Injection of cAMP into the sensory neurons, but not 5'AMP, evoked an increase in the amplitude of the EPSP at both the 3 $\mathrm{hr}$ and $24 \mathrm{hr}$ time points (Fig. 1A,B). The change in EPSP amplitude evoked by cAMP at $3 \mathrm{hr}$ was not different than the change measured at $24 \mathrm{hr}$. Starting from the same level of synaptic efficacy before experimental or control treatments $(21.7$ $\mathrm{mV} \pm 2.8$ vs $22.5 \mathrm{mV} \pm 3.5, p>0.8 ; 0 \mathrm{hr}$ ), injection with cAMP $(N=8)$ evoked significant increases of $7.6 \mathrm{mV}$ (to 29.3 $\mathrm{mV} \pm 2.7 ; p<0.04)$ by $3 \mathrm{hr}$ and $7.2 \mathrm{mV}(28.9 \mathrm{mV} \pm 3.4 ; p$ $<0.02)$ at $24 \mathrm{hr}$, while injection with 5'AMP $(N=8)$ resulted in small declines of $-3.2 \mathrm{mV}$ after $3 \mathrm{hr}(19.3 \mathrm{mV} \pm 3.4)$ and $-4.5 \mathrm{mV}(18.0 \mathrm{mV} \pm 2.5)$ after $24 \mathrm{hr}$.

The increases in EPSP amplitude evoked by cAMP were accompanied by structural changes in the sensory cell neurites that increased in magnitude over time (Figs. $1 C, 2$ ). After $3 \mathrm{hr}$, there was a net average increase of 7.0 varicosities in the number of sensory neuron varicosities contacting the major axonal processes of L7 $(30.8 \pm 3.2$ to $37.8 \pm 2.7)$ compared to a slight decline of -1.9 varicosities following injections with 5'AMP $(32.9 \pm 3.5$ to $31.0 \pm 2.8 ; p<0.01)$. The new varicosities with cAMP injections formed primarily as swellings along preexisting sensory cell neurites (Fig. $2 A, B$ ). With reexamination of the same cultures $21 \mathrm{hr}$ later, we observed that additional varicosities were formed on both preexisting and newly formed neurites (Fig. $2 C$ ) raising the net average increase to 11.3 varicosities (to $42.1 \pm 3.2 ; p<0.01)$. Approximately $2 / 3(67.5 \%)$ of the new varicosities formed by $3 \mathrm{hr}$ after injection were still present at $24 \mathrm{hr}$. At $24 \mathrm{hr}$, injection with 5'AMP resulted in a small decline of -3.1 varicosities (to $29.8 \pm 3.1$ ). Thus, cAMP elevation leads to structural changes in the sensory neuron that continue over a prolonged period and may serve to consolidate the change in synaptic efficacy expressed during short-term (Schacher et al., 1988, 1993) and intermediate-term time points.

\section{Activation of the PKC pathway evokes a large transient increase both in the efficacy of sensorimotor connections and in the number of sensory varicosities}

In previous studies, increases in PKC activity in sensory neurons significantly facilitated transmitter release for short durations (Braha et al., 1990), while persistent activation for at least $2 \mathrm{hr}$ failed to enhance the efficacy of the connection after $24 \mathrm{hr}$ (Schacher et al., 1988). Recent evidence indicates that treatments with 5-HT that evoke long-term facilitation lead to a persistent activation of some PKC isoforms for about 2-3 hr (Sossin et al., 1994). To test whether persistent activation of the PKC pathway can produce facilitation at intermediate time points, we examined both the change in synaptic efficacy and in sensory cell structure as described above both $1 \mathrm{hr}$ and $24 \mathrm{hr}$ after a $2 \mathrm{hr}$ incubation with phorbol ester.

Incubation with phorbol, but, not the inactive $\alpha$-phorbol, evoked a significant increase in the amplitude of the EPSP at the intermediate time point ( $3 \mathrm{hr}$ ), but not after $24 \mathrm{hr}$ (Fig. $3 A, B$ ). Starting from the same level of synaptic efficacy before experimental or control incubations $(29.7 \mathrm{mV} \pm 2.5 \mathrm{vs} 26.5 \mathrm{mV} \pm$ $5.2, p>0.6$; $0 \mathrm{hr}$ ), phorbol evoked a significant increase of at least $27.3 \mathrm{mV}$ (to $57.0 \mathrm{mV} \pm 3.0 ; p<0.01 ; N=6$ ) by $3 \mathrm{hr}$ compared to a small decline of $-1.7 \mathrm{mV}$ (to $24.8 \mathrm{mV} \pm 4.5$ ) following incubation with $\alpha$-phorbol $(N=6)$. The large change in EPSP amplitude evoked with phorbol at $3 \mathrm{hr}$ is an underestimate of the actual level of facilitation, since in four of six cultures the stimulus to the sensory neuron evoked an action potential in the motor cell (measured as a $60 \mathrm{mV}$ EPSP) despite

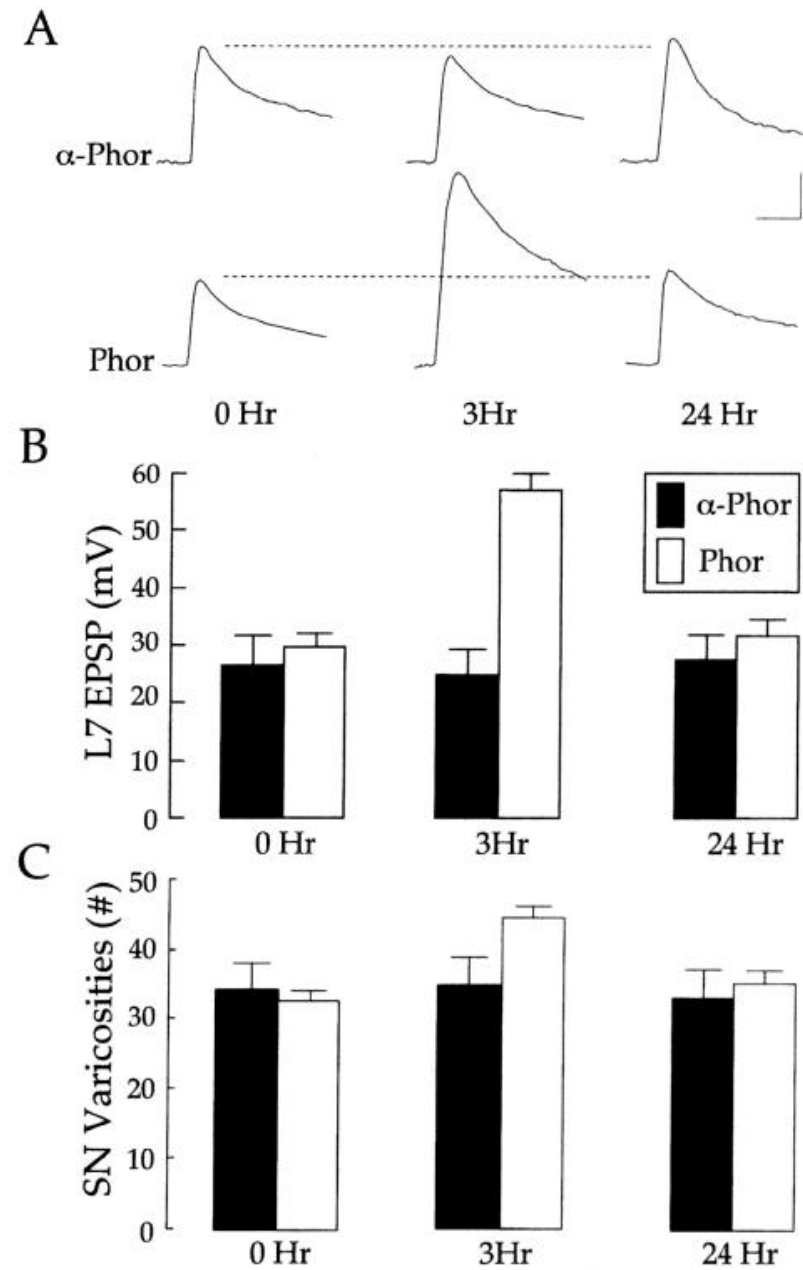

Figure 3. PDBU evoked transient functional and structural changes in the SN-L7 connections. $A$, The efficacy of the connection is enhanced by PDBU at $3 \mathrm{hr}$, but not at $24 \mathrm{hr}$. EPSPs were recorded before $(0 \mathrm{hr})$ and twice after treatment $(3 \mathrm{hr}$ and $24 \mathrm{hr}$ ). Whereas the amplitude of the EPSP was unchanged with $\alpha$-phorbol (top, $\alpha$-Phor), PDBU (Phor) increased significantly the EPSP amplitude at $3 \mathrm{hr}$. By $24 \mathrm{hr}$ the EPSP amplitude returned to baseline. The vertical bar equals $10 \mathrm{mV}$, and the horizontal bar equals $10 \mathrm{msec}$. $B$, Summary of the changes in EPSP amplitude evoked by $\alpha$-phorbol ( $\alpha$-Phor, solid bars) and PDBU (Phor, open bars). The height of each bar is the average amplitude of the EPSP at each time point. A two-factor ANOVA indicated a significant effect of treatment over time $(\mathrm{df}=2,20, F=74.423, p<0.001)$. One-factor ANOVA and $t$ tests indicated that PDBU evoked a significant change in the EPSP amplitude at the $3 \mathrm{hr}$ time point, but not at the $24 \mathrm{hr}$ time point. $C$, Summary of the changes in the number of sensory neurons varicosities evoked by $\alpha$-phorbol and PDBU. The height of each bar is the average number of sensory varicosities at each time point. A twofactor ANOVA indicated a significant effect of treatment over time (df $=2,20, F=32.654, p<0.001$ ). One-factor ANOVA and $t$ tests indicated that PDBU evoked a significant change in varicosity number at the $3 \mathrm{hr}$ time point, but not at the $24 \mathrm{hr}$ time point.

the fact that the motor cell was hyperpolarized by $30 \mathrm{mV}$ (from -80 to $-95 \mathrm{mV}$ ) below their resting potential. Similar large short-term facilitation can be evoked in some sensorimotor cultures with application of $2 \mu \mathrm{M} 5$-HT. By $24 \mathrm{hr}$ however, the amplitudes of the EPSP in cultures treated with phorbol had returned to approximately pretreatment levels (to $31.8 \mathrm{mV} \pm$ 2.8 ) and were no longer significantly different than those treated with inactive $\alpha$-phorbol $(27.5 \mathrm{mV} \pm 4.4 ; p>0.4)$.

The return to baseline was not accompanied by long-term 

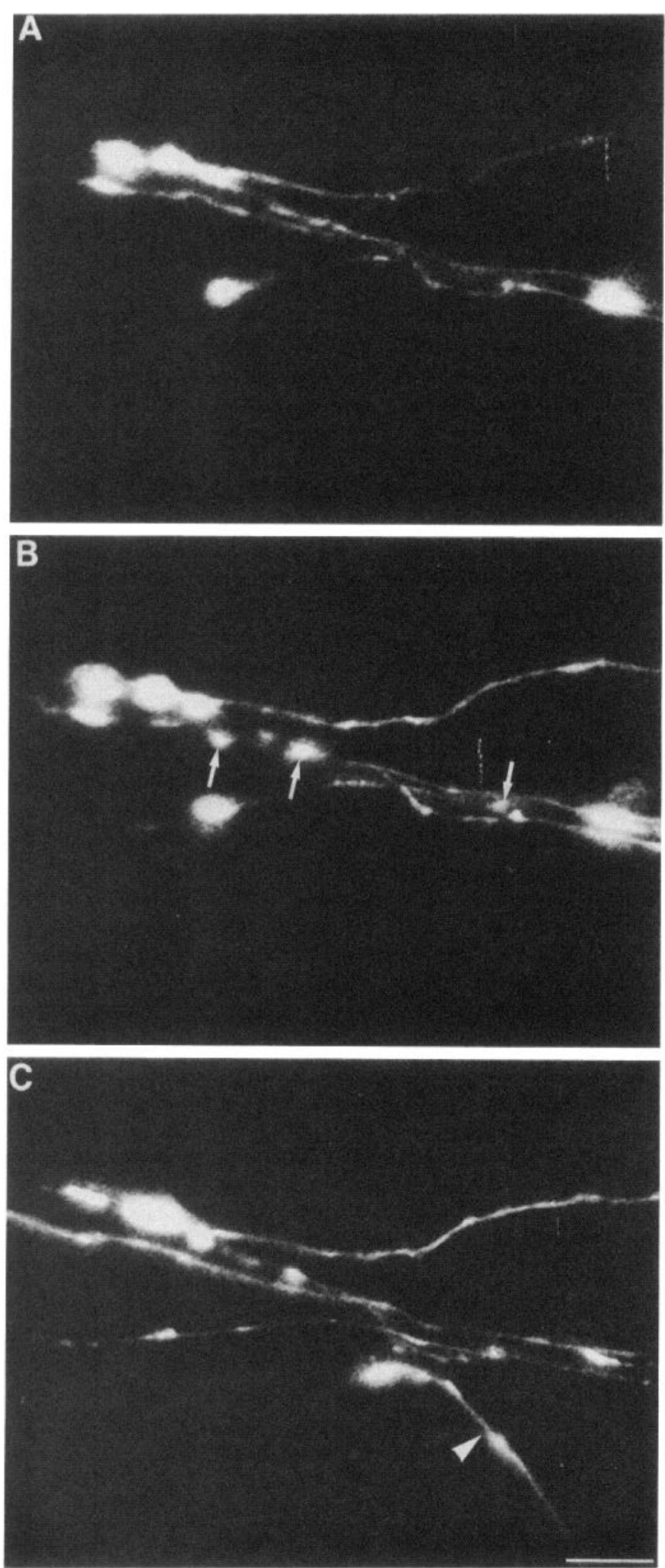

Figure 4. PDBU evoked a transient change in the structure of the sensory neurons. A, Epifluorescent view of a portion of the sensory cell neurites and varicosities in contact with the major motor axon (middle third of micrograph in horizontal plane) before treatment with PDBU. Image is a superimposition of two focal planes. $B$, View of the same area in A $3 \mathrm{hr}$ after onset of PDBU incubation. Three new varicosities have formed in this region (arrows). Overall, this sensory neuron gained 11 varicosities. $C$, View of the same area at $24 \mathrm{hr}$. Note that two of the new varicosities (indicated by the left and right arrows in $B$ ) are no inactivation of the PKC pathway as a consequence of phorbol treatment. A second application of phorbol $24 \mathrm{hr}$ after the first application $(N=5)$ evoked an increase of $18.6 \mathrm{mV} \pm 3.8 \mathrm{in}$ the EPSP amplitude that was not significantly different than the increase of $17.5 \mathrm{mV} \pm 4.0$ evoked by phorbol treatment of cultures exposed initially to $\alpha$-phorbol $(N=4)$. Moreover, $24 \mathrm{hr}$ after phorbol $(N=4)$ or $\alpha$-phorbol $(N=4)$, application of 5-HT to sensorimotor synapses first depressed by homosynaptic depression increased EPSP amplitudes by comparable levels $(338 \% \pm 17 \%$ vs $366 \% \pm 26 \%)$.

The transient increase in EPSP amplitude evoked by phorbol was accompanied by a parallel transient change in the structure of the sensory cell neurites (Figs. $3 C, 4$ ). At the intermediate time point $(3 \mathrm{hr})$ there was a significant net average increase of 12.0 varicosities in the number of sensory neuron varicosities contacting the major axonal processes of L7 (from $32.7 \pm 1.5$ to $44.7 \pm 1.7$ ) compared to a net change of 0.5 varicosities following incubation with $\alpha$-phorbol (from $34.3 \pm 3.9$ to 34.8 $\pm 4.1 ; p<0.01)$. As was the case with cAMP, the new varicosities appear to form primarily as swellings along preexisting sensory cell neurites (Fig. 4A,B; and see below). However, unlike the results observed with cAMP, the net change in the number of varicosities was no longer significantly different at $24 \mathrm{hr}$ $(p>0.6)$. The net number of varicosities declined on average by -9.5 (from the $3 \mathrm{hr}$ time point to $35.3 \pm 2.0$ at $24 \mathrm{hr}$ ), and was not significantly different than the number of varicosities contacting the motor axons in control cultures at $24 \mathrm{hr}$ (33.7 \pm 4.0). Thus, increase in PKC activity alone is not sufficient for maintaining the large change in synaptic efficacy evoked at short and intermediate time points.

The decline in varicosity number $24 \mathrm{hr}$ following treatment with phorbol was not a result of a general decline in the health of the cells. First, most of the decline in varicosities was selective and was primarily accounted for by the loss of the newly formed varicosities. Nearly $3 / 4(71.0 \%)$ of the new varicosities formed at $3 \mathrm{hr}$ were eliminated at $24 \mathrm{hr}$. Moreover, after washout the cells continued to extend occasional new branches with varicosities contacting the motor axon (Fig. $4 C$ ). The formation of new varicosities by $3 \mathrm{hr}$ was not due to a rapid increase in new outgrowth by the sensory cells. Treatment of $3 \mathrm{~d}$ cultures $(N=$ 22) of sensory neurons with $50 \mathrm{~nm}$ phorbol results in a significant reduction in neurite extension and an increase in the frequency of growth cone retractions (Figs. 5, 6). Whereas treatment of sensory neuron cultures with the control $\alpha$-phorbol $(N$ $=18$ ) had little effect on neurite extension and fasciculation with other sensory neurites (Fig. $5 A 1, A 2$ ), treatment with phorbol often resulted in a slowing of growth cone advance leading to the formation of a terminal varicosity (growth cone indicated by the left arrows in Fig. $5 B 1, B 2$ ), a retraction of the main body of the growth cone by $30-60 \mu \mathrm{m}$ (growth cones indicated by the center and right arrows in Fig. $5 B$ ), or a slowing of growth cone advance to an average of less than $15 \mu \mathrm{m}$ per hour (compared to $26 \mu \mathrm{m}$ per hour for sensory cell growth cone advance in cultures treated with $\alpha$-phorbol and $23 \mu \mathrm{m}$ per hour for untreated cultures). Nearly $2 / 3(65.4 \% \pm 4.5)$ of sensory neuron growth cones extend at a rate greater than $10 \mu \mathrm{m}$ per hour with

$\leftarrow$

longer present. A new branch bearing a varicosity (arrowhead) has appeared over this time period. Overall there was no net change in varicosities in this region compared to that observed at $0 \mathrm{hr}$. Scale bar, $15 \mu \mathrm{m}$. 

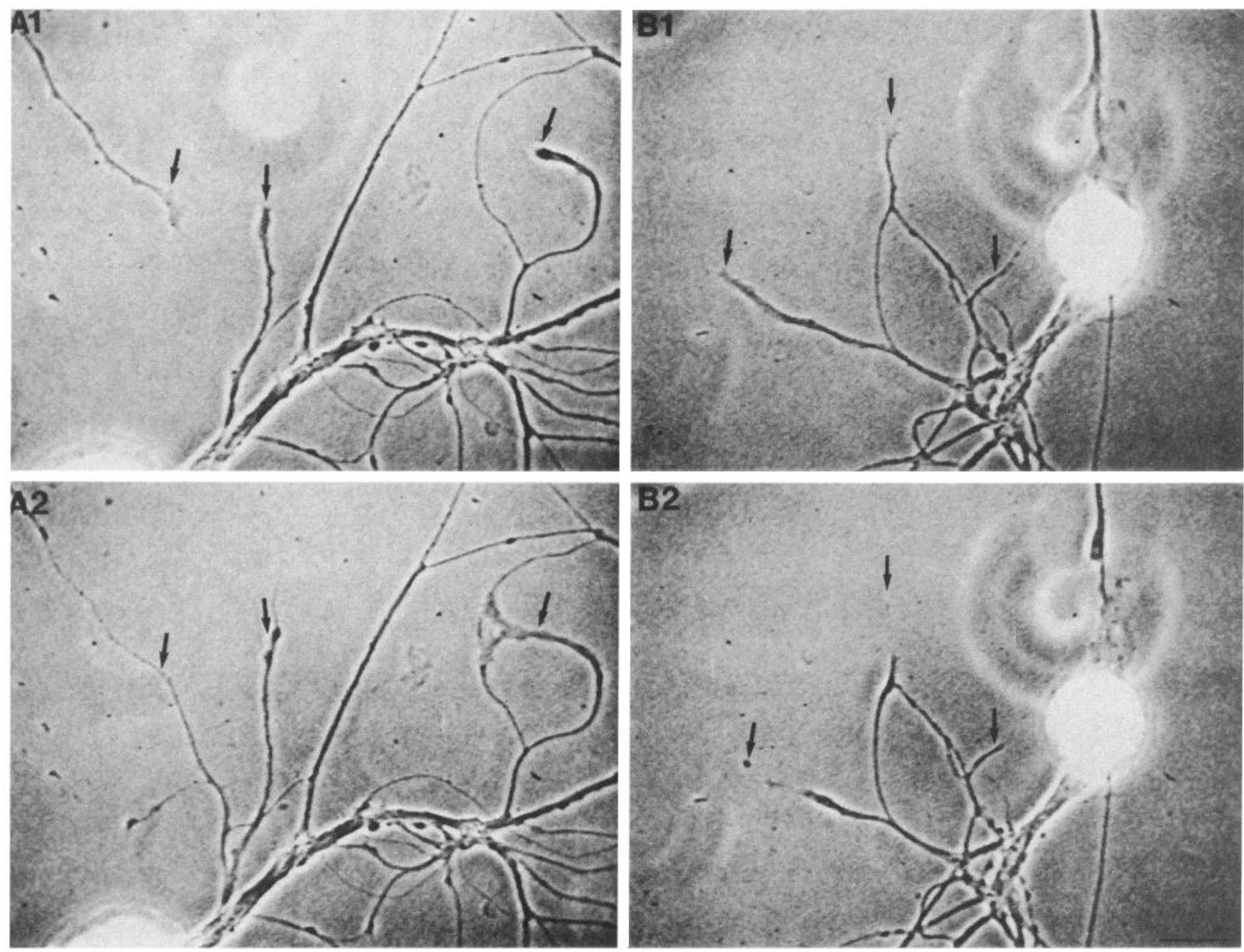

Figure 5. PDBU reduced growth of sensory neuron growth cones. A, Treatment with $\alpha$-phorbol did not affect growth cone extension or fasciculation. Growth cones before $(A l)$ and after $(A 2)$ treatment are indicated by arrows. Each growth cone extended, and some (right arrow) fasciculated with other sensory cell neurites. $B$, Treatment with PDBU halted extension and/or increased growth cone retractions. Growth cones before (BI) and after (B2) treatment are indicated by arrows. Each has appeared to retract, with some leaving behind a terminal varicosity connected to the retracted body of the growth cone by a thin process (left arrow). Scale bar, $30 \mu \mathrm{m}$.

control treatment compared to less than $30 \%(29.7 \% \pm 5.0 ; p$ $<0.01$ ) of growth cones showing the same behavior with treatment with phorbol (Phor, Fig. 6). In addition, treatment with phorbol facilitated the detection of what appear to be preexisting swellings along the neurites (numerous locations in Fig. 5B2). With washout of phorbol ( $N=11$ cultures), there was a resumption of growth by the growth cones that have stopped or retracted. By $4 \mathrm{hr}$ after washout the frequency of advancing growth cones $(76.1 \% \pm 3.3)$ was not significantly different $(p$ $>0.2$ ) than that observed for control treatment (Fig. 6). Thus, the change in the structure of sensory neurons (increase in the number of varicosities) evoked by phorbol in the cocultures is likely to be due to a reversible alteration in the structure of the preexisting sensory cell neurites.

\section{Discussion}

The results indicate that increases in the activity of either protein kinase (PKA or PKC) evoke changes in the efficacy of sensorimotor connections lasting from minutes to hours, but they differ in their capacity to evoke long-term facilitation lasting days. Increases in activity of either kinase can enhance transmitter release from preexisting terminals in a manner that is characteristic of short-term facilitation (Castellucci et al., 1980, 1982; Klein et al., 1986; Schacher et al., 1988; Braha et al., 1990; Sugita et al., 1992; Emptage and Carew, 1993; Schacher et al., 1993). With large and persistent activation of either kinase, changes in synaptic efficacy lasting $3 \mathrm{hr}$ were accompanied by significant changes in the structure of the sensory neurons. The failure of the increase in PKC activity to parallel the increase PKA activity in evoking long-term changes (greater than $24 \mathrm{hr}$ ) in synapse efficacy may reflect the differences of the two kinase pathways in maintaining or stabilizing the initial kinase-induced structural changes in the sensory neurons. Whereas the new varicosities induced by cAMP persisted and continued to increase in number, the PDBU-induced changes in sensory neuron structure were transient. It is unlikely that the reversal of these functional and structural changes are a consequence of PDBU-induced inactivation of the PKC pathways in either the sensory or motor neurons, since the effects of PDBU treatment were reversible and the cells responded to subsequent treatments that involved additional activation of the PKC pathway (Braha et al., 1990). 


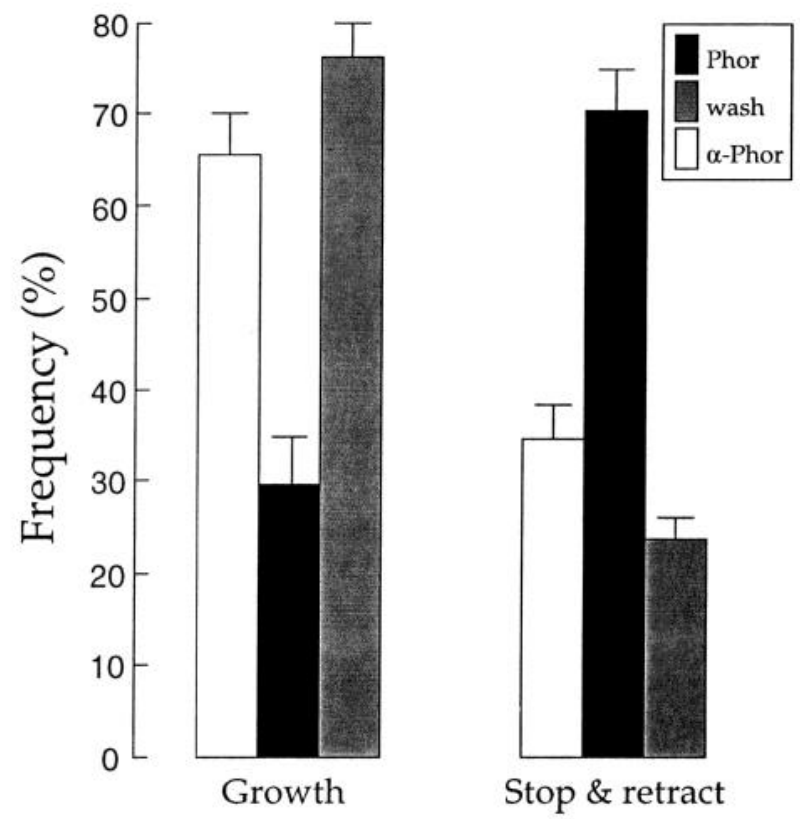

Figure 6. The reduction in growth cone advance by PDBU is reversible. The height of each bar is the average frequency \pm SEM per culture for a given growth cone behavior. PDBU (Phor) evoked a significant reduction in the proportion of sensory growth cones that advance and a significant increase in the proportion of growth cones that have either stopped or retracted $(\mathrm{df}=2,48, F=27.615, p<0.001)$. The growth cones that have either stopped or retracted can resume growth following washout of PDBU (wash).

Although we did not examine directly whether the new sensory neuron varicosities contained transmitter release sites, several previous studies indicated a strong correlation between the number of presynaptic varicosities and the amplitude of the EPSP evoked in motor cell L7 both before and after the induction of long-term modulation of the connections (Glanzman et al., 1989a, 1990; Schacher and Montarolo, 1991; Bailey et al., 1992; Schacher et al., 1993). Electron microscope examination of the sensory neuron contacts with the major motor axons either before or after treatments that evoke long term facilitation (Glanzman et al., 1989a, 1990; Schacher et al., 1991) indicated that these varicosities typically contained active zones characteristic of sensory neuron transmitter release sites (Bailey and Chen, 1983). In addition to the contributions of the new varicosities at the intermediate time point, enhancement of transmitter release at pre-existing varicosities induced by persistent kinase activity may contribute to the overall change in synaptic efficacy (Kandel and Schwartz, 1982; Sossin and Schwartz, 1994; Ghirardi et al., 1995). Thus, changes in the release properties of preexisting terminals plus the structural changes may contribute to the facilitation at the intermediate time point. The correlations between the persistent increase in synaptic efficacy following PKA activation and the decline in efficacy following PKC activation with the capacity to maintain the new sensory neuron varicosities are consistent with the hypothesis that some aspects of the long-term "consolidation" of the functional changes of the connection are mediated by the structural changes (Bailey and Chen, 1988, 1989; Glanzman et al., 1990; Schacher et al., 1993).

The apparent duplicative nature of the short-term changes in synaptic efficacy evoked by increases in the activity of either kinase raises the question of whether kinase activation by their respective receptors to 5-HT simply reflects a redundant feature to insure appropriate responses by the cells. Earlier studies suggested that increases in the activity of either kinase can contribute to an enhancement in synapse efficacy by evoking shortterm changes in excitability and action potential duration and/or by directly evoking changes in transmitter release (Klein et al., 1986; Braha et al., 1990; Sugita et al., 1992; Klein, 1993, 1994; Ghirardi et al., 1995). These latter changes evoked by increased activity of either kinase may be especially critical when the available "pool" of vesicular release of transmitter has been reduced by prior activity (Gingrich and Byrne, 1985; Hochner et al., 1986). The overall consequence of increasing the activity of both kinases under these conditions may insure an appropriate response by the neurons. Both pathways could also play important roles in the expression of short- versus long-term plasticity following local site-specific activation of specific 5-HT receptor subtypes (Clark and Kandel, 1993; Emptage and Carew, 1993). Behavioral stimuli resulting in the release of 5-HT at the sensory neuron cell body leading to the local increase in the appropriate kinase activities would evoke a long-term change in the properties of the connections. Moreover, the results reported here suggest that the persistent activation of the PKC pathway could contribute to the large functional changes in synaptic efficacy evoked by 5 -HT concentrations capable of evoking long-term plasticity (Ghirardi et al., 1995) during the transition between the expression of short- and long-term synaptic plasticity. Thus changes in the activity of both kinases evoked by 5-HT may be additive and contribute to the large functional changes at intermediate times.

The transient functional and structural changes evoked by PDBU are most likely a consequence of its direct actions on preexisting sensory cell neurites and varicosities. Unlike the changes evoked by increases in PKC activity in some regenerating systems (Hsu, 1985; Bixby, 1989; Lankford and Letourneau, 1991), the application of PDBU during the active phase of regeneration of Aplysia sensory neurons did not enhance neurite outgrowth. Treatment resulted in a significant reduction in growth cone extension, as well as an increase in the frequency of growth cone retractions. By contrast, 2 hr treatment with forskolin or cAMP analogues did not reduce neurite extension by sensory neurons (Wu and Schacher, unpublished observations). Although the expression of changes in neurite extension, growth cone behavior and structure evoked by PDBU were obvious after $2 \mathrm{hr}$, changes in the structure of growth cones could be observed within 15-30 min of treatment. This suggest that enhanced PKC activity is most likely affecting protein substrates directly within the growth cone that might affect motility and shape. Because both the reduction of neurite outgrowth and significant facilitation of sensorimotor synapses with PDBU occur rapidly (Braha et al., 1990; Sugita et al., 1992), it is possible that the rapid functional and structural changes observed at $3 \mathrm{hr}$ were consequences of the persistent increase in PKC activity on protein substrates within the preexisting sensory neurites and varicosities (Knox et al., 1992). The local effect of PDBU on existing neurites is consistent with the observations that both the change in behavior by sensory growth cones and the change in varicosity number are transient. The new varicosities formed as a result of PDBU treatment are the ones that are most susceptible to elimination.

The long-term maintenance of new sensory neuron varicosities induced by appropriate stimuli after stable connections have formed apparently requires increases in PKA activity within the 
sensory neurons. This would trigger appropriate changes in the nucleus of the sensory neuron for regulating expression of synapse-specific macromolecules (Schacher et al,, 1988; Nazif et al., 1991; Backsai et al., 1993; Hu et al., 1993; Alberini et al., 1994). The changes in the sensory neuron soma would include PKA-induced changes in the regulatory machinery for transcription (Dash et al., 1990; Kaang et al., 1993; Alberini et al., 1994) and the expression, synthesis, and transport of macromolecules needed for both the formation of new terminals as well as their maintenance (Forscher et al., 1987; Schacher et al., 1988, 1993; Bailey et al., 1992; Funte and Haydon, 1993; Hu et al., 1993). In addition, increases in PKA activity in the sensory neuron may be required to trigger appropriate long-term changes in the postsynaptic motor cell such as the formation of new postsynaptic receptive zones for the new presynaptic structures (Irudeau and Castellucci, 1995). Stabilization of new varicosities may also require cAMP-induced alterations in the relative expression of adhesion molecules on the surface of the interacting cells (Mayford et al., 1992; Hu et al.. 1993; Wu and Schacher, 1994: Zhu et al., 1995). Changes in the level of expression of adhesion molecules and their ligands on the surface of the cells could signal changes in other intracellular cascades affecting kinase activities (Atashi et al., 1992; Doherty and Walsh, 1992). In addition to changes in the activities of PKA and PKC, 5-HT may also affect the activities of CaM kinase (Saitoh and Schwartz, 1983, 1985) or others (Homayouni et al., 1995). The nature of this reciprocal sequence of intercellular and intracellular signals initiated by the binding of 5-HT to multiple receptor subtypes and the role of various protein kinases and their interactions in regulating both pre- and postsynaptic cells in the formation and stabilization of new synaptic connections require further study.

\section{References}

Abeliovich A, Chen C, Goda Y, Silva AJ, Stevens CF Tonegawa S (1993) Modified hippocampal long-term potentiation in PKC gamma-mutant mice. Cell 75:1253-1262.

Acosta-Urquidi J, Alkon DL, Neary JT (1984) Calcium-dependent protein kinase injection in a photoreceptor mimics biophysical effects of associative learning. Science 224:1254-1257.

Akers RF, Lovinger DM, Colley PA, Linden DJ, Routtenberg A (1986) Translocation of protein kinase $\mathrm{C}$ activity may mediate hippocampal long term potentiation. Science 231:587 589 .

Alberini CM, Ghirardi M, Metz R, Kandel ER (1994) C/EBP is an immediate early gene required for the consolidation of long-term facilitation in Aplysia. Cell 76:1099-1114.

Atashi JR, Klinz SG, Ingraham CA, Matten WT, Schachner M, Maness PF (1992) Neural cell adhesion molecules modulate tyrosine phosphorylation of tubulin in nerve growth cone membranes. Neuron $8: 831-842$.

Backsai BJ. Hochner B, Mahaut-Smith M. Adams SR, Katang B, Kandel ER, Tsien RY (1993) Spatially resolved dynamics of cAMP and protein kinase A subunits in Ap/ysia sensory neurons. Science 260: 222-226.

Bailey CH, Chen M (1983) Morphological basis of long-term habituation and sensitization. Science 220:91-93.

Bailey CH, Chen M (1988) Long-term memory in Aplysia modulates the total number of varicosities of single identified sensory neurons. Proc Natl Acad Sci USA 85:2373-2377.

Bailey $\mathrm{C} \mathbf{H}$, Chen $\mathbf{M}$ (1989) Time course of structural changes at identified sensory neuron synapses during long-term sensitization in Aplysia. J Neurosci 9:1774-1780.

Bailey CH, Montarolo PG. Chen M, Kandel ER, Schacher S (1992) Inhibitors of protein and RNA synthesis block the structural changes that accompany long-term heterosynaptic plasticity in the sensory neurons of Aplysia. Neuron 9:749-758.

Bank M, Schacher S (1992) Segregation of presynaptic inputs on an identified target neuron in vitro: structural remodeling visualized over time. J Neurosci 12:2960-2972.

Baxter DA, Byrne JH (1990) Differential effects of cAMP and seroIonin on membrane cument, action potential duration, and excitability in somata of pleural sensory neurons of Aplysia. J Neurophysiol 64: 978-990.

Bergold PJ, Sweatt JD, Winicov I, Weiss KR, Kandel ER, Schwartz JH (1990) Protein synthesis during acquisition of long-term facilitation is needed for the persistent loss of regulatory subunits of the Aplysia cAMP-dependent protein kinase. Proc Natl Acad Sci USA 87:37883791.

Bernier L, Castellucci VF, Kandel ER, Schwartz JH (1982) Facilitatory transmitter causes a selective and prolonged increase in cyclic AMP in sensory neurons mediating the gill and siphon withdrawal reflex in Aplysia. J Neurosci 2:1682-1691.

Bixby JL (1989) Protein kinase C is involved in laminin stimulation of neurite outgrowth. Neuron 3:287-297.

Bourtchuladze R, Frenguelli B, Blendy J, Cioffi D, Schutz G, Silva AJ (1994) Deficient long-term memory in mice with a targeted mutation of the cAMP-responsive element-binding protein. Cell 79:59-68.

Boyle MB, Klein M, Smith SJ, Kandel ER (1984) Serotonin increases intracellular $\mathrm{Ca}^{2+}$ transients in voltage clamped sensory neurons of Aplysia californica. Proc Natl Acad Sci USA 81:7642-7646.

Braha O. Dale N, Hochner B, Klein M, Abrams TW, Kandel ER (1990) Second messengers involved in the two processes of presynaptic facilitation that contribute to sensitization and dishabituation in Aplysia sensory neurons. Proc Natl Acad Sci USA 87:2040-2044.

Braha O, Edmonds B, Saktor T, Kandel ER, Klein M (1993) The contributions of protein kinase $\mathrm{A}$ and protein kinase $\mathrm{C}$ to the actions of 5-HT on L-type $\mathrm{Ca}^{+2}$ channels of the sensory neurons in Aplysia. J Neurossi 13:1839-1851.

Brunelli M, Castellucci VF, Kandel ER (1976) Synaptic facilitation and behavioral sensitization in Aplysia: possible role of serotonin and cyclic AMP. Science 194:1178-1181.

Castellucci VF, Kandel ER, Schwartz JH, Wilson AC, Nairn A, Greengard P (1980) Intracellular injection of the catalytic subunit of cyclic AMP-dependent protein kinase stimulates facilitation of transmitter release underlying behavioral sensitization in Aplysia. Proc Natl Acad Sci USA 77:7492-7496.

Castellucci VF, Nairn AC, Greengard P, Schwartz. JH, Kandel ER (1982) Inhibitor of cAMP-dependent protein kinase blocks presynaptic facilitation in Aplysia. J Neurosci 2:1673-1681.

Clark GA, Kandel ER (1993) Induction of long-term facilitation in Aplysia sensory neurons by local application of serotonin to remote synapses. Proc Natl Acad Sci USA 90:11411-11415.

Corfas G, Dudai Y (1991) The morphology of a sensory neuron in Drosophila is abnormal in memory mutants and changes during aging. Proc Natl Acad Sci USA 88:7252-7256.

Critz SD, Byrne JH (1992) Modulation of $I_{K_{A}}$ by phorbol ester-mediated activation of PKC in pleural sensory neurons of Aplysia. J Neurophysiol 68:1079-1086.

Dale N. Kandel ER (1990) Facilitatory and inhibitory transmitters modulate spontaneous transmitter release at cultured Aplysia sensorimotor synapses. J Physiol (Lond) 421:203-222.

Dale N, Schacher S, Kandel ER (1988) Long-term facilitation in Aplysia involves increase in transmitter release. Science 239:282-285.

Dash PK, Hochner B, Kandel ER (1990) Injection of the cyclic AMP responsive element into the nucleus of Aplysia sensory neurons blocks long-term facilitation. Nature 345:718-721.

Dixon D. Atwood HL (1989) Adenylate cyclase system is essential for long-term facilitation at the crayfish neuromuscular junction. J Neurosci 9:4246-4252.

Doherty P, Walsh FS (1992) Cell adhesion molecules, second messengers and axonal growth. Curr Opin Neurobiol 2:595-601.

Emptage NJ, Carew TJ (1993) Long-term synaptic facilitation in the absence of short-term facilitation in Aplysia neurons. Science 262: $253-256$.

Farley J, Auerbach S (1986) Protein kinase C activation induces conductance changes in Hermissenda photoreceptors like those seen in associative learning. Nature 319:220-223.

Forscher P, Kaczmarek LK, Buchanan J Smith SJ (1987) Cyclic AMP induces changes in distribution and transport of organelles within growth cones of Aplysia bag cell neurons. J Neurosci 7:3600-3611.

Frey U, Huang Y-Y, Kandel ER (1993) Effects of cAMP simulate a 
late stage of LTP in hippocampal $C \wedge 1$ neurons. Science 260:1661 1664.

Funte LR, Haydon PG (1993) Synaptic target contact enhances presyraptic calcium influx by activating cAMP-dependent protein kinase during synaptogenesis. Neuron 10:1069-1078.

Ghirardi M, Braha O, Hochner B, Montarolo PG, Kandel ER Dale N (1992) Roles of PKA and PKC in facilitation of evoked and spontaneous transmitter release at depressed and nondepressed synapses in Aplvisia sensory neurons. Neuron 9:1-20.

Ghirardi M, Montarolo PG, Kandel ER (1995) A novel intermediate stage in the transition between short- and long-term facilitation in the sensory to motor neuron synapse of Aplysia. Neuron 14:413-420.

Gingrich KJ, Byrne JH (1985) Simulation of synaptic depression, posttetanic potentiation and presynaptic facilitation of synaptic potentials from sensory neurons mediating the gill withdrawal reflex in Aplysia. J Neurophysiol 53:652-669

Glanzman DL, Kandel ER, Schacher S (1989a) Identified target motor neuron regulates neurite outgrowth and synapse formation of Aplysia sensory neurons in vitro. Neuron 3:441-450.

Glanzman DL, Kandel ER, Schacher S (1990) Target-dependent structural changes accompanying long-term synaptic facilitation in Aplysia neurons. Science 249:799-802.

Glanzman DL, Mackey SL, Hawkins RD, Dyke AM, Lloyd PE. Kandel ER (1989b) Depletion of serotonin in the nervous system of Aplysia reduces the behavioral enhancement of gill withdrawal as well as the heterosynaptic facilitation produced by tail shock. J Neurosci 9:4200 4213.

Grant SGN, O'dell TJ. Karl KA, Stein PL, Soriano P, Kandel ER (1992) Impaired long-term potentiation, spatial learning, and hippocampal development in fyn mutant mice. Science 258:1903-1910.

Greenberg SM, Castellucci VF, Bayley H, Schwartz JH (1987) A molecular mechanism for long-term sensitization in Aplysia. Nature 329: $62-65$.

Hochner B, Klein M, Schacher S, Kandel ER (1986) Additional components in the cellular mechanism of presynaptic facilitation contributes to behavioral dishabituation in Aplysia. Proc Natl Acad Sci USA 83:8794-8798.

Homayouni R, Byrne JH, Eskin A (1995) Dynamics of protein phosphorylation in sensory neurons of Aplysia. J Neurosci 15:429-438.

Hsu L (1985) Neurite-promoting effects of TPA on chick embryo neurons. Neurosci Lett 62:283-289.

Hu GY, Hvalby O, Walaas SI, Albert KA, Skjeflo P, Andersen P, Greengard $P$ (1987) Protein kinase C' injection into hippocampus pyramidal cells elicits features of long-term potentiation. Nature 328:426429 .

Hu Y, Barzilai A, Chen M, Bailey CH, Kandel ER (1993) 5-HT and cAMP induce the formation of coated pits and vesicles and increase the expression of clathrin light chain in sensory neurons of Aplysia. Neuron 10:921-929.

Huang Y-Y, Li X-C, Kandel ER (1994) cAMP contributes to mossy fiber LTP by initiating both a covalently mediated early phase and macromolecular synthesis-dependent late phase. Cell 79:69-79.

Kaang B-K, Kandel ER, Grant SGN (1993) Stimuli that produce longterm facilitation in Aplysia sensory neurons activate the transcription of cAMP-responsive genes. Neuron 10:427-435

Kandel ER, Schwartz JH (1982) Molecular biology of learning: modulation of transmitter release. Science 218:433-443.

Klein M (1993) Differential cyclic AMP dependence of facilitation at Aplysia sensorimotor synapses as a function of prior stimulation: augmentation versus restoration of transmitter release. J Neurosci 13: 3793-3801.

Klein M (1994) Synaptic augmentation by 5-HT at rested Aplysia sen sorimotor synapses: independence of action potential prolongation Neuron 13:159-166.

Klein M, Camardo J, Kandel ER (1982) Serotonin modulates a specific potassium current in the sensory neurons that show presynaptic facilitation in Aplysia. Proc Natl Acad Sci USA 79:5713-5717.

Klein M, Hochner B, Kandel ER (1986) Facilitatory transmitters and cAMP can modulate accommodation as well as transmitter release in Aplysia sensory neurons: evidence for parallel processing in a single cell. Proc Natl Acad Sci USA 83:7994-7998.

Knox RJ, Quattrocki EA, Connor JA, Kaczmarek LK (1992) Recruitment of calcium channels by protein kinase $\mathrm{C}$ during rapid formation of putative neuropeptide release sites in isolated Aplysia neurons. Neuron 8:883-889.
Lankford KL, Letourneau PC (1991) Roles of actin filaments and threc second-messenger systems in short-term regulation of chick dorsal root ganglion neurite outgrowth. Cell Motil Cytoskel 20:7-29.

Malenka RC, Kauer JA, Perkel DJ, Mark MD, Kelly PT, Nicholl RA, Waxham NN (1989) An essential role for postsynaptic calmodulin and protein kinase activity in long-term potentiation. Nature 340 : $554-557$

Malinow R, Madison DV, Tsien RW (1988) Persistent protein kinase activity underlying long-term potentiation. Nature 335:820-824.

Malinow R, Shulman H, Tsien RW (1989) Inhibition of postsynaptic PKC or CAMKII blocks induction but not expression of LTP. Science 245:862-866

Mayford M, Barzilai A, Keller F, Schacher S, Kandel ER (1992) Modulation of an NCAM-related adhesion molecule with long-term synaptic plasticity in Aplysia. Science 256:638-644.

McGlade-McCulloh E, Yamamoto H, Tan SE, Brickey DA. Soderling TR (1993) Phosphorylation and regulation of glutamate receptors by calcium/calmodulin dependent protein kinase II. Nature 362:640 642

Mercer AR, Emptage NJ, Carew TJ (1991) Pharmacological dissociation of modulatory effects of serotonin in Aplywia sensory neurons. Science 254:1811-1813.

Miller B, Sarantis M, Traynelis SF, Attwell D (1992) Potentiation of NMDA receptor currents by arachidonic acid. Nature 355:722-725.

Montarolo PG, Goelet P, Castellucci VF, Morgan J, Kandel ER, Schacher $S$ (1986) $\wedge$ critical time window for macromolecular synthesis in long-term heterosynaptic facilitation in Ap/ysia. Science 234:12491254.

Nazif FA, Byrne JH, Cleary LJ (1991) Cyclic AMP induces long-term morphological changes in sensory neurons of Aplysia. Brain Res 539: 324-327.

Occor KA, Byrne JH (1985) Membrane responses and changes in cyclic AMP levels in Aplysia neurons by serotonin, tryptamine, FMRFamide, and small cardioactive peptide (SCPb). Neurosci Lett $55: 113-118$

O'dell TJ, Kandel ER, Grant SGN (1991) Long-term potentiation in the hippocampus is blocked by tyrosine kinase inhibitors. Nature 353 : 558-560.

Peter N, Aronoff B, Wu F, Schacher S (1994) Decrease in growth coneneurite fasciculation by sensory or molor cells in vimo accompanies modulation of Ap/ysia cell adhesion molecules by neurotransmitters. J Neurosci 14:1413-1421.

Raymond LA, Blackstone CD, Huganir RL (1993) Phosphorylation and modulation of recombinant GluR6 glutamate receptors by CAMPdependent protein kinase. Nature 361:637-641.

Rayport SG, Schacher S (1986) Synaptic plasticity in vitro: cell culture of identified Aplysia neurons mediating short-term habituation and sensitization. J Neurosci 6:759-763.

Saitoh T, Schwartz JH (1983) Serotonin alters the subcellular distribution of a $\mathrm{Ca}^{+2} / \mathrm{calmodulin}$ binding protein in neurons of $\mathrm{Apl}$ ysia. Proc Natl Acad Sci USA 80:6708-6712.

Saitoh T, Schwartz JH (1985) Phosphorylation-dependent subcellular translocation of a $\mathrm{Ca}^{+2} / \mathrm{calmodulin-dependent} \mathrm{protein} \mathrm{kinase} \mathrm{produces}$ an autonomous enzyme in Aplysia neurons. J Cell Biol 100:835-842.

Saktor TC, Schwartz JH (1990) Sensitizing stimuli cause translocation of protein kinase $\mathrm{C}$ in Aplysia sensory neurons. Proc Natl Acad Sci USA 87:2036-2039.

Schacher S (1985) Differential synapse formation and neuritic outgrowth at two branches of the metacerebral cell of Aplysia in discociated cell culture. J Neurosci 5:2028-2034.

Schacher S, Montarolo PG (1991) Target-dependent structural changes in sensory neurons of Aplysia accompany long-term heterosynaptic inhibition. Neuron 6:679-690.

Schacher S, Proshansky E (1983) Neurite regeneration by Aplysia neurons in dissociated cell culture: modulation by Aplysia hemolymph and the presence of the initial axon segment. I Neurosci 3:24032413.

Schacher S, Castellucci VF, Kandel ER (1988) Cyclic AMP evokes long-term facilitation in Aplysia sensory neurons that requires new protein synthesis. Science 240:1667-1669.

Schacher S, Montarolo PG, Kandel ER (1990) Selective short- and long-term effects of serotonin, small cardioactive peptide, and tetanic stimulation on sensorimotor synapses of Aplysia in culture. J Neurosci 10:3286-3294.

Schacher S, Glanzman DL, Barzilai A, Dash P, Grant SGN, Keller F. 
Mayford M, Kandel ER (1991) Long-term facilitation in Aplysia: persistent phosphorylation and structural changes. Cold Spring Harb Symp Quant Biol 55:187-202.

Schacher S, Kandel ER, Montarolo PG (1993) cAMP and arachidonic acid simulate long-term structural and functional changes produced by neurotransmitters in Aplysia sensory neurons. Neuron 10:10791088.

Scholz KP. Byrne JH (1987) Long-term sensitization in Aplysia: biophysical correlates in tail sensory neurons. Science 235:685-687.

Scholz KP, Byrne JH (1988) Intracellular injection of cyclic AMP induces a long-term reduction of neuronal potassium currents. Science 240:1664-1667.

Schuman EM, Clark GA (1994) Synaptic facilitation at connections of Hermissenda type B photoreceptors. J Neurosci 14:1613-1622.

Siegelbaum SA, Camardo JS, Kandel ER (1982) Serotonin and cAMP close single $\mathrm{K}^{+}$channels in Aplysia sensory neurons. Nature 299: 413-417.

Silva AJ, Stevens CF, Tonegawa S, Wang Y (1992) Deficient hippocampal long-term potentiation in calcium-calmodulin kinase II mutant mice. Science 257:201-206.

Sossin WS, Schwartz JH (1992) Selective activation of calcium-activated PKCs in Aplysia neurons by 5-HT. J Neurosci 9:3218-3229.

Sossin WS, Saktor TC, Schwartz JH (1994) Persistent activation of protein kinase $\mathrm{C}$ during the development of long-term facilitation in Aplysia. Learning Memory 1:189-202.

Sugita S. Goldsmith JR, Baxter DA, Byrne JH (1992) Involvement of protein kinase $\mathrm{C}$ in serotonin-induced spike broadening and synaptic facilitation of sensorimotor connections in Aplysia. J Neurophysiol 68:613-651.

Sugita S, Baxter DA, Byrne JH (1994) Activators of protein kinase C mimic serotonin-induced modulation of a voltage-dependent potas- sium current in pleural sensory neurons of Aplysia. J Neurophysiol $72: 1240-1249$

Sweatt JD, Kandel ER (1989) Persistent and transcriptionally dependent increase in protein phosphorylation in long-term facilitation of Aplysia sensory neurons. Nature 339:51-54.

Trudeau L-E, Castellucci VF (1995) Postsynaptic modifications in long-term facilitation in Aplysia: upregulation of excitatory amino acid receptors. J Neurosei 15:1275-1284.

Walsh JP, Byrne JH (1989) Modulation of a steady state $\mathrm{Ca}^{+2}$-activated $\mathrm{K}^{+}$current in tail sensory neurons of Aplysia: role of serotonin and cAMP. J Neurophysiol 61:32-44.

Wang LY, Dudek EM, Browning MD, MacDonald JF (1994) Modulation of AMPA/kainate receptors in cultured murine hippocampal neurons by protein kinase C. J Physiol (Lond) 475:431-437.

Weisskopf MG, Castillo PE, Zalutsky RA, Nicholl RA (1994) Mediation of hippocampal mossy fiber long-term potentiation by cyclic AMP. Science 265:1878-1882.

Wojtowicz JM, Marin L, Atwood HL (1989) Synaptic restructuring during long-term facilitation at the crayfish neuromuscular junction. Can J Physiol Pharmacol 67:167-171.

Wu F, Schacher S (1994) Pre- and postsynaptic changes mediated by two second messengers contribute to expression of Aplysia long-term heterosynaptic inhibition. Neuron 12:407-421.

Zhong Y, Wu C-F (1991) Altered synaptic plasticity in Drosophila memory mutant with altered cAMP cascade. Science 25 1:1562-1564.

Zhu H, Wu F, Schacher S (1994) Aplysia cell adhesion molecules and serotonin regulate sensory cell-motor cell interactions during early stages of synapse formation in vitro. J Neurosci 14:6886-6900.

Zhu H, Wu F, Schacher S (1995) Changes in the expression and distribution of Aplysia cell adhesion molecules can influence synapse formation and elimination in vitro, J Neurosci 15:4173-4183. 